\title{
OVERVIEW OF THE PARANÁ'S PLAN FOR CONTROL OF VEHICLE POLLUTION
}

\author{
REGINALDO JOAQUIM DE SOUZA \\ Instituto Superior de Administração e Economia - ISAE, Brazil
}

\begin{abstract}
The plan for control of vehicle pollution was developed by the government of Paraná, a state located in the south of Brazil, to create an awareness among the community regarding the importance of changing urban mobility culture - which otherwise might have a dramatic impact over the next few years. The inventory shows that Curitiba has one of the highest vehicles/inhabitant ratios in the country, which affects air quality; considerable increase in pollution is noticeable and such increase is due to use of fossil fuels, mainly diesel. The increase of the vehicles fleet over the past 5 years has caused air quality to decrease and now Curitiba has 0.8 vehicle per person. The purpose of the plan is to report changes to the fleet, fostering the use of alternative transportation and ensuring a regular mechanical maintenance of all the fleet to reverse the current trend.

Keywords: air quality, automotive emission, carbon dioxide, inventory, mobile source, Paraná's vehicles plan, PCPV Paraná
\end{abstract}

\section{INTRODUCTION}

Since the First National Atmospheric Emissions from Road Vehicles Inventory carried out by the Ministry of Environment coordinated by the IEMA - Energy and Environment Institute in 2011, no report has been published until that period. We have a very concerning scenario on the growth of the Brazilian vehicles fleet and atmospheric pollutants emissions regulated by air quality programmes PROCONVE (Program for the control of air pollution by road vehicles) and PROMOT (Program for the control of air pollution by motorcycles and similar vehicles). Some of the main pollutants are carbon monoxide $(\mathrm{CO})$, nitrogen oxides $\left(\mathrm{NO}_{\mathrm{x}}\right)$, non-methane hydrocarbons (NMHC), aldehydes (RCHO) and particulate material (MP), other than greenhouse gases, carbon dioxide $\left(\mathrm{CO}_{2}\right)$ and methane $\left(\mathrm{CH}_{4}\right)$. A reason for concern is that $53 \%$ of $\mathrm{CO}_{2}$ emissions in tonnes have resulted from diesel coming from the road transportation sector in 2009, whereas the scenario expected for 2020 will be 180 million tonnes of $\mathrm{CO}_{2}$ resulting from diesel, corresponding to $40 \%$ [1].

According to Sachs, 'the growing demand for power started with the internal combustion engine back in the nineteenth century. He says that the energy waste is the main factor impacting the quality of life, as well as it has huge consequences on climate change. Managing the use of fuels in an efficient manner is connected to economic calculation, since every tonne of oil-equivalent energy used in the world releases 2.4 tons of $\mathrm{CO}_{2}$ emissions. The accurate amount of $\mathrm{CO}$ depends on the power source' [2].

On the other hand, the article prepared by Vijayaraghavan et al. [3] has analysed the effects of ozone and particulate matter emissions from gasoline-powered vehicles in the United States. The article presents some scenarios of emission projections based on two models of light vehicles and cars. The pollutants analysed include $\mathrm{NO}_{x}, \mathrm{VOC}$ and PM 2.5 and PM10. In one of the scenarios obtained 'emissions from gasoline-fueled light duty vehicles (LDVs) in four urban areas in 2022 has a decrease from $77.5 \%$ for $\mathrm{NO}_{x}, 63 \%$ for VOC and $21.1 \%$ for PM 2.5' [3].

According to Sachs 'a metric ton is 1000 kilograms, so that 0.19 of a ton is 190 kilograms; therefore for every US\$ 1,000 of production, we use about 190 kilos of oil or its equivalent in energy content.' 
For further knowledge about emissions, a more accurate inventory is necessary, in that sense the work of researchers [4] has established a model to determine the mobile sources in the eastern United States seasonally, mainly determining the ozone concentrations in the atmosphere. The emission inventory development and processing for the seasonal model for regional air quality used a MOBILE 5 software on the available data of the emission factor provided by EPA (Environmental Protection Agency) and the miles traveled by vehicles to elaborate the inventory.

The point highlighted by the authors [4] is that the model shall have a quality control verification to determine its accuracy, even if it uses the validated data of fuel vehicles and estimates of pollution sources by month. Hence a temporal data analysis is required by analysing the sum of emission factors based on pollutant type and plume type formed on the evaluated pollutants of $\mathrm{NO}_{\mathrm{x}}$, collected in the base structure of $\mathrm{NO}_{2}$ and then converted into $\mathrm{NO}_{2}$ and NO. The source categories of topical emissions for the model have been used (area, biogenic, mobiles and fixed sources), and only the nitrogen oxides $\left(\mathrm{NO}_{\mathrm{x}}\right)$ and reactive organic Compounds (ROC) and carbon monoxide have been considered.

The Fraunhofer Institute [5] has conducted a study to assist the European Community with the development of a vehicles logistics strategy for the transportation of passengers and cargo. The aim of this work is to determine the carbon footprint in the transportation sector. This document will support the public policies on 'mobility/logistics, as well as economic, social, and environmental public policies along with other impacts of these political choices'. The definition of a model for the calculation of the carbon footprint not only applies to companies but also applies to end users and drivers. An example implementation of the policy is the creation of a standard label provided to those end users and drivers who declare their $\mathrm{CO}_{2}$ on the scope of the vehicle. It would be a carbon footprint measure to emissions control through labelling that certified vehicle for 'emissions per shipment, consignment, shipper or passenger'. Another way is for the passengers and shippers to choose their transport vehicle which can be biofuel-powered vehicles, electric vehicles or less-carbon-impact footprint transport.

The research conducted by Prevedouros e Mitropoulos [6] established a model for calculating emission life cycle of light commercial vehicles, with the purpose of identifying the costs of gasoline, electricity and hydrogen-powered vehicles. According to the authors, the vehicle powered by hydrogen had the best performance on the fuel efficiency paired with low cost of production and had one of the shortest atmospheric emission life cycles when compared to other types of vehicles.

The increase in the global fleet of vehicles is related to the better financial and economic conditions of the population. This causes alarming consequences on the quality of life of the population and has an impact on the air quality and climate. Data provided by EPA [7] show that the transportation sector was responsible for $28 \%$ of $\mathrm{CO}_{2}$ emissions, which is equivalent to those produced by fossil fuels; most of such emissions came from light commercial vehicles [7].

To achieve an efficient air quality management, CONAMA - the National Environment Council - enacted Resolução CONAMA 418 of 2009 [8], aiming to 'set the criteria for the establishment of Vehicle Pollution Control Plans - PCPV and for the Implementation of Inspection and Maintenance Programs for Vehicles in Use - I/M - by the state and municipal environmental agencies and setting new emission limits and procedures for the evaluation of the conditions of maintenance of the vehicles in use'. This is an instrument of public policy for the states and municipalities, being led by the state in those states with fleet over three million road motors, and includes the preparation of plans containing the following information: I - the geographic extension and the regions to be prioritized; II - the target fleet and respective legal and technical bases; III - implementation schedule; IV - the kind of connection with the state registration system; V - the regularity of the inspection; VI - the economic analysis; and VII - the kind of integration, when applicable, with safety inspection programs and similar. 
With the implementation of this instrument the state of Paraná has created the Vehicle Pollution Control Plan in 2011 [9]; as part of this instrument the target fleet inventory has presented air quality indicators and proposed the vehicle inspection and maintenance execution model for the fleet covering the whole territory of Paraná. The main purpose of this article is to carry out a critical analysis on the effectiveness of the plan: if there was a reduction of fuel consumption by the user since the creation of the plan; if there was a reduction of 10-20\% in air pollutants emissions, $\mathrm{CO}$ and $\mathrm{CO}_{2}$ gas (indirectly) and if the vehicle/inhabitant ratio has decreased.

\section{METHODOLOGY}

The development of the research by compilation and analysis that collected the secondary data of the plan had already measured fleet and population figures from 2000 to 2010, in addition to some air pollutants such as the total suspended particles - TSP; fumes; inhalable particles - PI (other nomenclature names it PM10 or MP10); sulphur dioxide - $\mathrm{SO}_{2}$; carbon monoxide $-\mathrm{CO}$; ozone $-\mathrm{O}_{3}$; nitrogen dioxide $-\mathrm{NO}_{2}$. In addition, $\mathrm{CO}_{2}$ emissions as greenhouse effect gases. These data were being projected for the current scenario (2015) and were exacerbated for the 2020 scenario. We shall highlight that the fleet growth over the next 10 years since the last measurement has a significant contribution to the increase in pollution emissions, mainly concerning $\mathrm{CO}$ gas resulting from fuels combustion.

The data collection was based on the population (number of inhabitants), using as source the Geography and Statistics Brazilian Institute (IBGE) [10], collected for the period from 2000 to 2015, the data of the population of the state of Paraná. The fuel data have been collected from the National Agency for Petroleum, Natural Gas and Biofuels - ANP [11], with statistical data on the sales, by distributors, of petroleum by-products fuels (oil barrels equivalent) in the period from 2000 to 2015 in the state of Paraná, involving fuel types such as LPG, combustible oil, diesel oil, aviation kerosene, light kerosene, aviation gasoline and gasoline accounted for in tonnes. Concerning the vehicles fleet in the state of Paraná, the database used was that of the National Traffic Department - DENATRAN [12] in the state of Paraná involving vehicles licensed during 2000-2015. For the calculation of the amount of $\mathrm{CO}_{2}$, the bottom-up method has been used, mainly taking into consideration reliable local data concerning fuel quality, emissions factors and the fleet technology used. The Intergovernmental Panel on Climate Change (IPCC) itself suggests a data measurement for a detailed presentation of the information.

The calculation is very simple and was used as a reference for the carbon dioxide emission data factors for transportation activities in million BTU provided by the Energy Information Administration - EIA (http://www.eia.gov/oiaf/1605/coefficients.html\#tbl2): aviation gasoline 69.19, fuel diesel 73.15, ethanol 14.79, ethanol blend-E85 gasoline motor 71.26, aviation kerosene 70.88, natural gas 54.60, propane 63.07, oil fuel 78.80. The data obtained in $\mathrm{CO}_{2}$ equivalent tonnes [13].

The calculations of $\mathrm{CO}_{2}$ emissions have been made by using the following formula:

$$
\text { Emiss }_{\mathrm{i}}=\mathrm{FE}_{\mathrm{iabc}} \times \text { Activity }_{\mathrm{abc}}
$$

where:

Emiss $_{\mathrm{i}}=\mathrm{i}$ gas emissions;

$\mathrm{FE}_{\mathrm{i}}=\mathrm{i}$ gas emission factor;

Activity = amount of power spent or distance travelled;

$\mathrm{i}=\mathrm{CO}_{2}, \mathrm{CO} ; \mathrm{a}=$ type of fuel; $\mathrm{b}=$ type of vehicle; $\mathrm{c}=$ emissions control technologies 
To determine the amount of carbon monoxide pollutant, we try to be more specific regarding the producer-consumer process involving the fuels chain, which was made with the software GREET 2015, developed by the Energy Systems Division (ES) at Argonne National Laboratory, with the purpose of presenting total urban $\mathrm{CO}$ emissions (tonnes) in energetic terms by type of fuel and type of vehicle for specific emission factor by year from 2000 to 2015 [14].

In the data compilation for the first graphical analysis, we have used the software Minitab (version 17) [15]. In a quantitative research on data treatment applying the regression model, in the variable amount of $\mathrm{CO}_{2}$ eq. versus year, increasing growth in emissions is noticeable well above the plan's proposal, which would be an indirect reduction of $\mathrm{CO}_{2}$ emissions. Then if we look at the result for the $\mathrm{CO}$, in particular, the plan establishes a reduction of at least $10 \%$; we can also notice an increase over $59 \%$.

\section{RESULTS AND DISCUSSIONS}

The data have been collected by analysis of PCPV primary data and secondary data from IBGE sources as shown in Table 1 (Paraná population). According to the research, the authors [16] suggest the quantification of carbon dioxide in Dhaka urban area and the absorption of these emissions by planting tree corridors. Moreover, in this context they established that the total carbon dioxide emission by a specific type of vehicle might be derived from the multiplication of the emission factor by the number of type of vehicle derived from volume survey and the distance the vehicle has travelled in kilometre in a particular mode.

Table 1: Data of 16 samples of numerical category.

\begin{tabular}{cccccr}
\hline Year & $\begin{array}{c}\mathrm{CO}_{2} \text { eq. } \\
\text { (millions tonne) }\end{array}$ & $\begin{array}{c}\text { Vehicles fleet } \\
\text { (licensed units) }\end{array}$ & $\begin{array}{c}\text { Population } \\
\text { (millions of } \\
\text { inhab.) }\end{array}$ & $\begin{array}{c}\text { Fuels } \\
\text { (tonne) }\end{array}$ & $\begin{array}{c}\text { CO } \\
\text { Emissions } \\
\text { (tonne) }\end{array}$ \\
\hline 2000 & $15,022,274.19$ & $2,351,408$ & $9,665,334$ & $5,441,000$ & $46,969.45$ \\
2001 & $15,047,421.21$ & $2,532,257$ & $9,786,066$ & $5,443,000$ & $44,787.33$ \\
2002 & $15,074,531.26$ & $2,718,779$ & $9,903,412$ & $5,424,000$ & $42,978.90$ \\
2003 & $15,061,050.33$ & $2,929,662$ & $10,017,462$ & $5,427,000$ & $43,181.31$ \\
2004 & $15,461,932.64$ & $3,182,172$ & $10,128,262$ & $5,649,000$ & $47,518.76$ \\
2005 & $15,583,671.88$ & $3,488,343$ & $10,235,875$ & $5,694,000$ & $50,602.91$ \\
2006 & $15,294,878.68$ & $3,739,741$ & $10,340,390$ & $5,596,000$ & $49,157.63$ \\
2007 & $15,948,537.12$ & $4,077,232$ & $10,441,872$ & $5,896,000$ & $51,725.42$ \\
2008 & $16,876,003.94$ & $4,451,731$ & $10,540,407$ & $6,307,000$ & $56,059.39$ \\
2009 & $16,876,003.94$ & $4,789,454$ & $10,636,065$ & $6,254,000$ & $59,057.18$ \\
2010 & $18,153,420.94$ & $5,160,354$ & $10,728,961$ & $6,950,000$ & $72,140.17$ \\
2011 & $19,861,650.09$ & $5,558,521$ & $10,820,421$ & $7,321,000$ & $86,208.92$ \\
2012 & $21,418,534.29$ & $5,954,243$ & $10,910,374$ & $7,869,000$ & $91,370.81$ \\
2013 & $22,481,167.35$ & $6,311,809$ & $10,997,465$ & $8,369,000$ & $100,207.41$ \\
2014 & $23,158,662.39$ & $6,716,094$ & $11,081,692$ & $8,654,000$ & $127,473.72$ \\
2015 & $22,235,998.54$ & $6,959,319$ & $11,163,018$ & $8,530,000$ & $98,627.61$ \\
\hline
\end{tabular}




\section{ANALYSIS OF THE GROWTH OF CARBON DIOXIDE EMISSIONS}

In the analysis of the $\mathrm{CO}_{2}$ gas regression table in increasing order over the years, a correlation between the two variables is noticeable, and the correlation coefficient value is 0.95 as determined in Fig. 1. To confirm this evidence, the determination coefficient of $94.98 \%$ was found. The line graph has presented a better result concerning the data dispersion for the growth quadratic model and its regression equation for $\mathrm{X}$ and $\mathrm{Y}$ is as follows:

$$
\mathrm{Y}=1.99 \mathrm{E}+11-1.99 \mathrm{E}+08 \mathrm{X}+49608 \mathrm{X}^{\wedge} 2
$$

We can establish that the amount of $\mathrm{CO}_{2}$ generated is 198 million tonnes as shown in Fig. 2.

The regression graph indicates a trend of growth in $\mathrm{CO}_{2}$ eq. emissions, which might come in 2,020 to 30,154,327 million tonnes of $\mathrm{CO}_{2}$ eq. launched into the atmosphere influenced by fuel consumption. If we analyse what the Vehicle Pollution Control Plan was measured up to 2010 , and with a projection for 2020 we shall have a growth of $38.79 \%$ of the $18,454,812$ million tonnes of $\mathrm{CO}_{2}$ eq.

\section{ANALYSIS OF THE GROWTH OF CARBON MONOXIDE EMISSIONS}

In the analysis of the CO regression table in increasing order over the years, a correlation between the two variables is noticeable, and the correlation coefficient value determined is 0.95 as shown in Fig. 3. Following this evaluation, we also state that the determination coefficient found is $90.74 \%$. The line graph has presented a better result concerning the data dispersion for the positive growth quadratic model and has its regression equation for the variables $\mathrm{X}$ and $\mathrm{Y}$.

$$
Y=1.76 E+9-1754657 X+438.2 X^{\wedge} 2
$$

We can establish that the amount of $\mathrm{CO}$ generated is $1,754,657$ million tonnes as shown in Fig. 4.

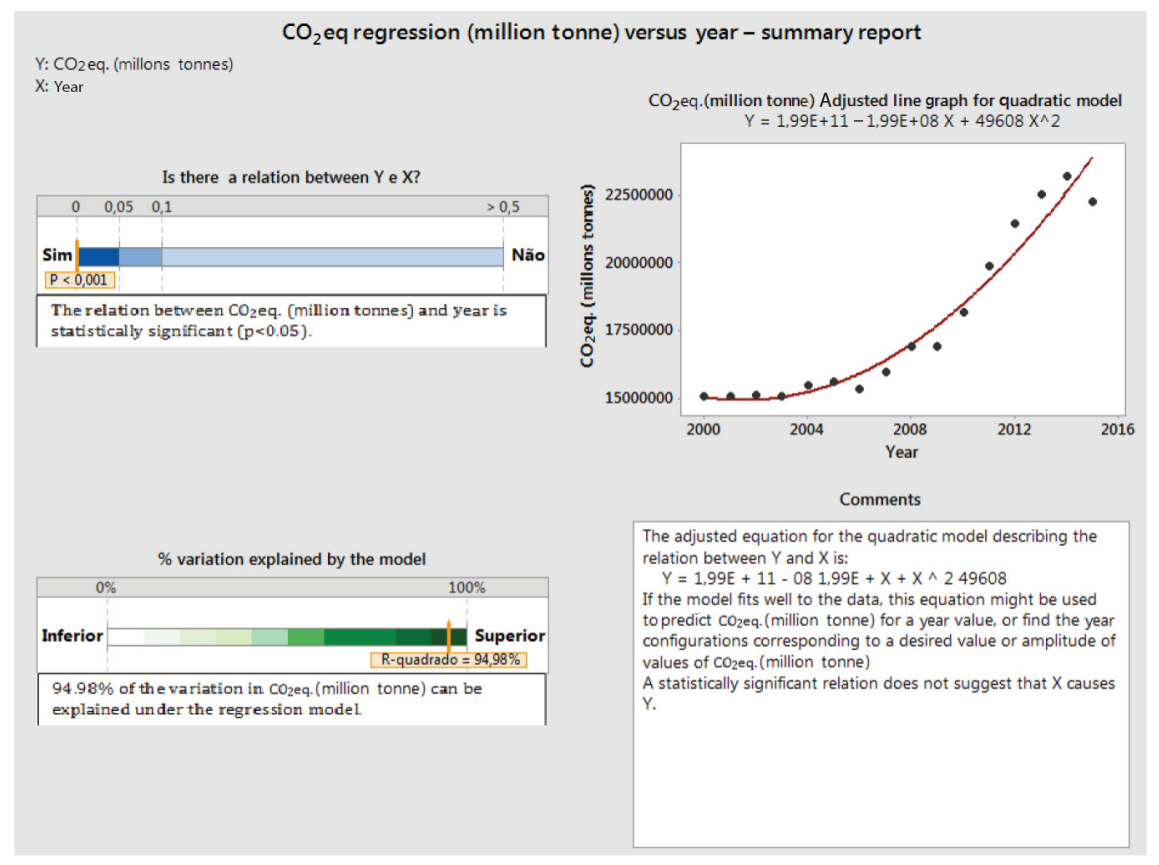

Figure 1: $\mathrm{CO}_{2}$ eq. regression graphic (M. tonnes) versus year. 


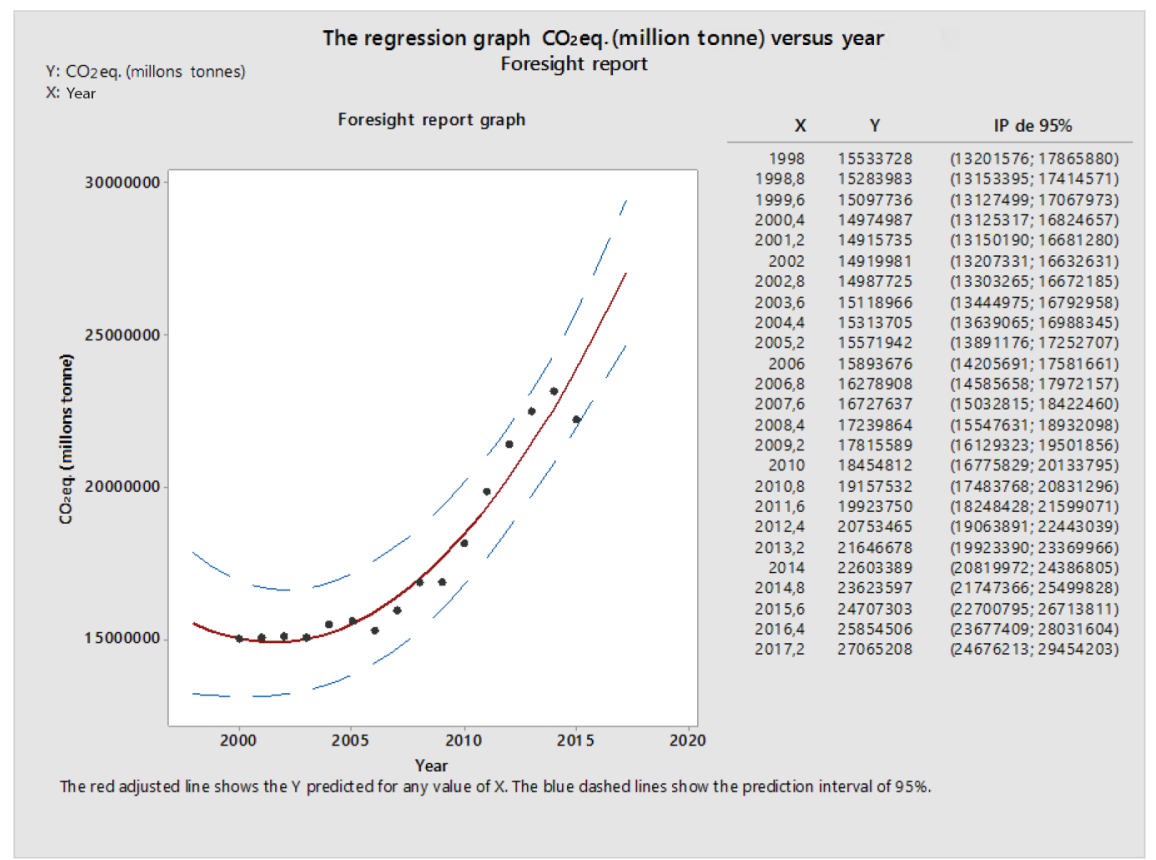

Figure 2: Projection graph up to $2020 \mathrm{CO}_{2}$ eq. (M. tonnes) versus year.

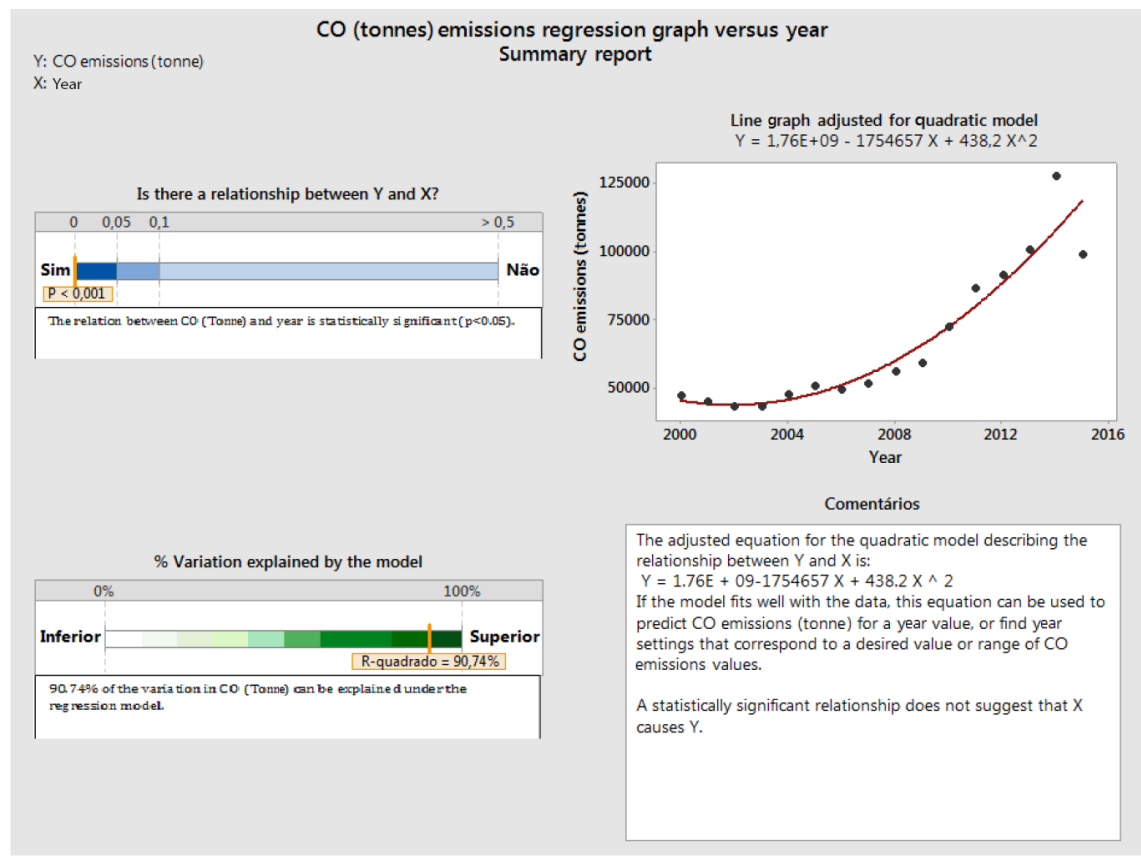

Figure 3: $\mathrm{CO}$ (tonnes) emissions regression graph versus year. 


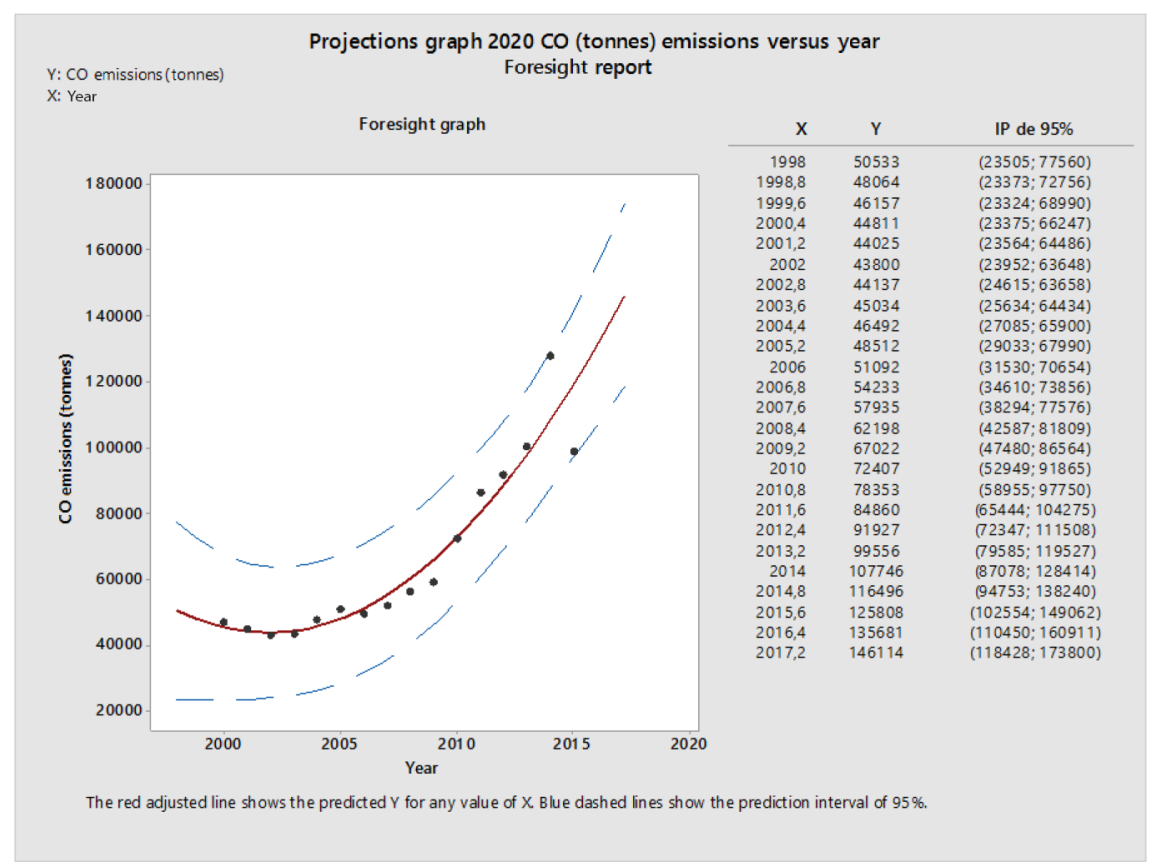

Figure 4: Projections graph 2020 CO (tonnes) emissions versus year.

The regression graph presents us a clear trend of growth in $\mathrm{CO}$ emissions, and in this scenario 2020 might see 180,430 thousand tonnes of CO launched into the atmosphere largely due to fuel consumption. If we analyse that the Vehicle Pollution Control Plan has measured up to 2010, and with a projection for 2020, we shall have a growth of 59.86 (180,430 tonnes) as compared to the 72,407 thousand tonnes measured in 2010 .

\section{ANALYSIS OF THE GROWTH OF THE VEHICLES FLEET OF THE STATE OF PARANÁ}

In the graph presented, we can notice a correlation between the variables population growth and the increasing order of years as shown in Fig. 5. The linear correlation coefficient value between the variable of the vehicles fleet of the state of Paraná (millions of licensed units) and the year is 0.995 . Another value that determines the correlation determination coefficient value is $99.93 \%$. In the analysis, the increasing regression graph is almost a linearity and the regression equation is determined as follows.

Vehicles fleet (millions of licensed units) $=-641425175+321722$ year, meaning an annual growth rate of $3.5 \%$ which corresponds to 321,722 licensed units per year as shown in the temporal graph in Fig. 6.

As we can notice in the graph, the fleet growth has an almost linear trend throughout the sampling period, whereas the growth of the carbon dioxide emissions from 2011, after the preparation of the plan, has been above the period when measured, in the meanwhile the fuel growth also kept a growth trend from 2011 as we can notice in the graph. 


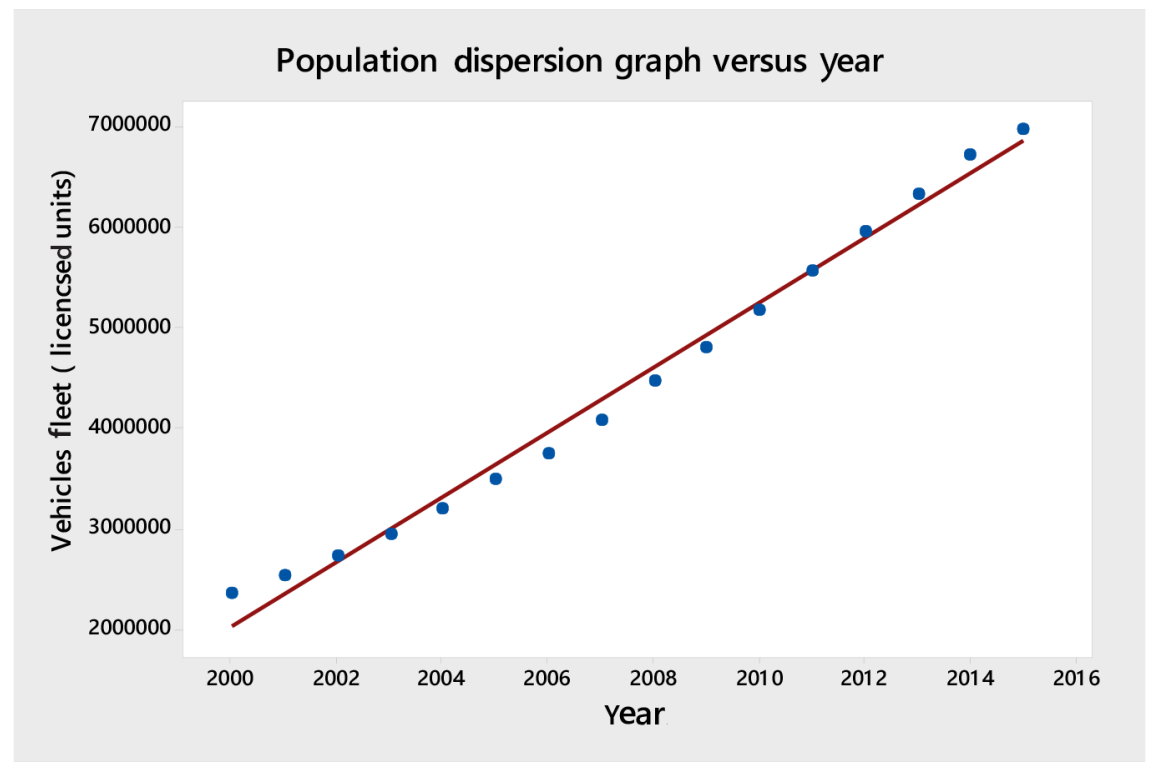

Figure 5: Dispersion graph vehicles fleet Paraná vehicles versus year.

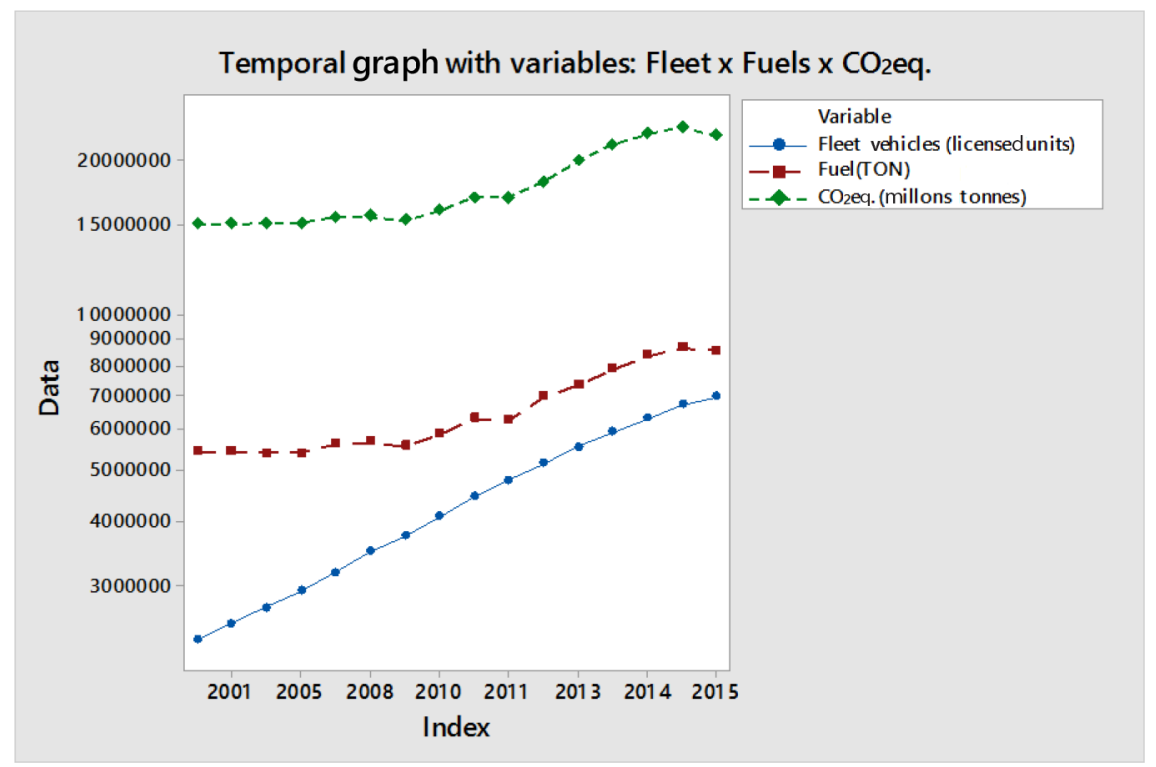

Figure 6: Temporal graph with variables: Fleet $\times$ Fuels $\times \mathrm{CO}_{2}$ eq.

\section{ANALYSIS OF THE GROWTH OF THE POPULATION BESIDE YEARS IN THE PARANÁ STATE}

In the dispersion graph presented, we can notice the existence of a correlation between the variables population growth and the increasing order of years appear as shown in Fig. 7. The linear correlation coefficient value between the population variable (millions of inhab.) and the year is 0.998 . Another value determined to confirm this correlation is the determination 


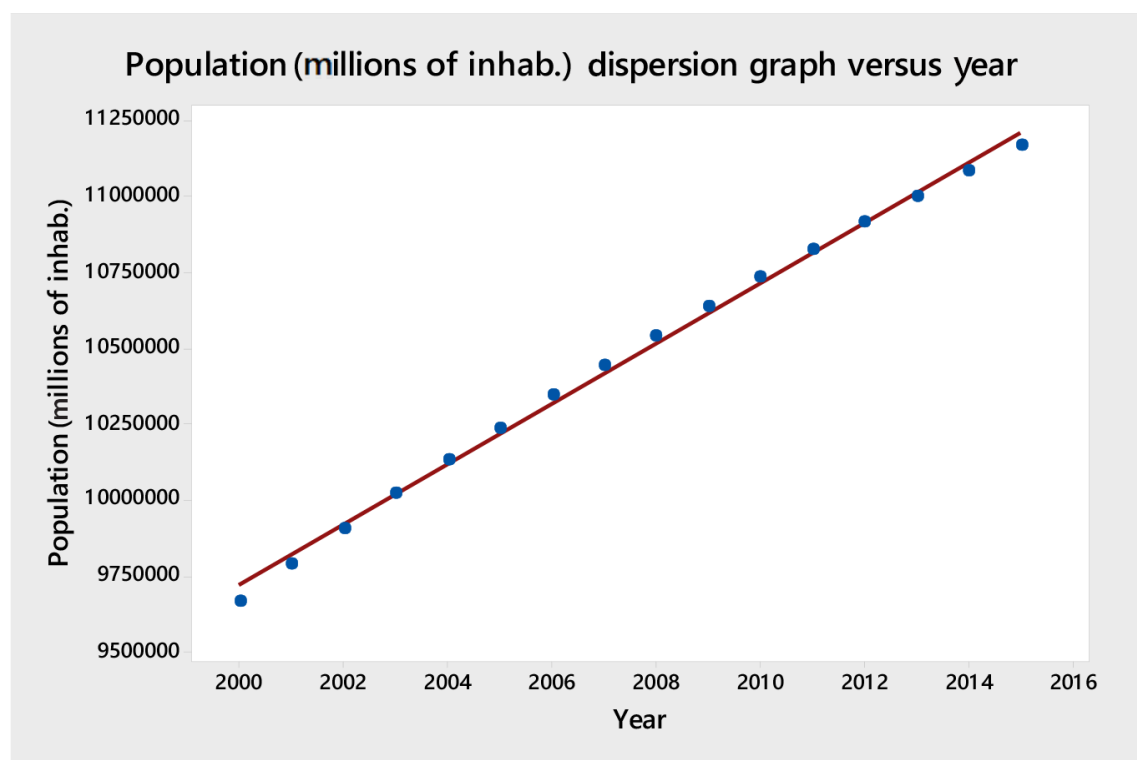

Figure 7: Population dispersion graph versus year.

coefficient value of $99.68 \%$. In the analysis, the increasing regression graph has an almost perfect linearity and its regression equation is determined from Fig. 8 as follows.

Population (millions of inhab.) $=-189329078+99522$ year, which means an annual growth rate of $1 \%$ corresponding to 99,522 inhabitants per year.

In the analysis of the regression graph with projection of the vehicles fleet of the state of Paraná versus the population of the state of Paraná, we can notice the existence of a correlation between the two variables, and the correlation coefficient value determined is 0.95 . Following this evaluation, we also state that the determination coefficient found is $99.92 \%$. The line graph presents a better result concerning the data dispersion for the positive growth quadratic model and with the trend result we can evaluate that the indicator measuring this growth is the number of vehicles per inhabitant, which is 139 vehicles for every 100 inhabitants, an increase of 2.83 as compared to the 2011 plan (with data up to 2010).

\section{CONCLUSION}

The state of Paraná has always been one of the pioneers when it comes to atmospheric emissions, from the elaboration of public policies in the legal field to the transportation modal BRT (Bus Rapid Transport), which is a world class reference, with a system of tubes allowing the buses to be powered by alternate fuels, such as biodiesel. It also has an Air Quality Network currently featuring 11 monitoring stations in the metropolitan area of Curitiba [17]. They monitor the atmospheric pollutants from primary and secondary sources, such as the total suspended particles - PTS; fumes; inhalable particles - PI (another nomenclature could be PM10 or MP10); sulphur dioxide - $\mathrm{SO}_{2}$; carbon monoxide - $\mathrm{CO}$; ozone $-\mathrm{O}_{3}$; nitrogen dioxide $-\mathrm{NO}_{2}$. Currently using as reference for the emission of these pollutants the Resolution SEMA No 16 on the criteria for air quality control is one of the basic instruments of environmental management to protect the population's health and welfare as well as to improve the quality of life in order to foster the social and economic development of the state in an environmentally safe fashion establishing: 


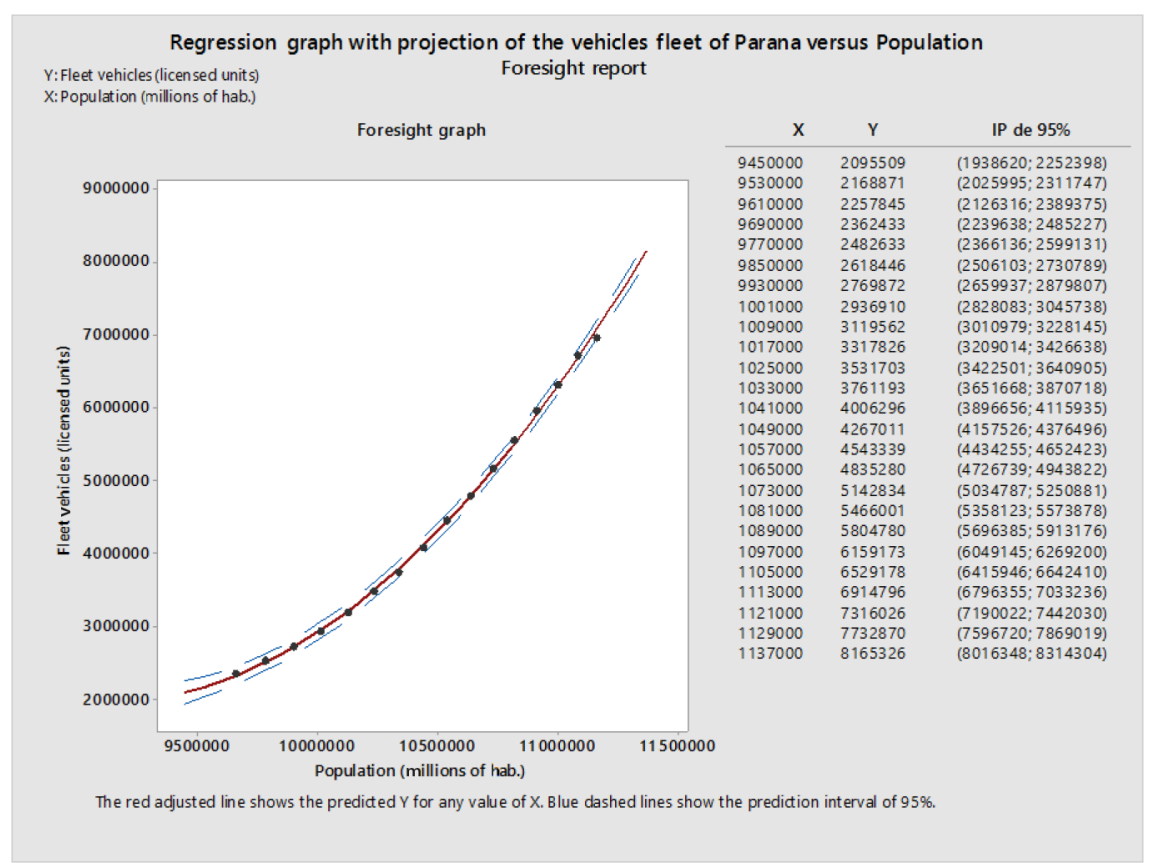

Figure 8: Regression graph with projection of the vehicles fleet of the state of Paraná versus the population.

'I - emission standards and service criteria for industrial, commercial and services sources; II - conditioning standards;

III - methodologies to be used for the determination of emissions' [18].

If we look at the results, the impact on the process of increase in the main greenhouse gas $\mathrm{CO}_{2}$ eq. and the increase of toxic pollutant gases such as $\mathrm{CO}$ is evident despite the limiting factor which is the small data sampling for the research in the correlation and application of the regression function. However, the research refers only to the data of the state of Paraná, whereas the analysis consists exactly of checking whether the plan is contributing to the reduction of pollutants and the implementation of renewable fuels in the transportation power system. There was a progress in some isolated actions occurring mainly in the metropolitan area of Curitiba such as the implementation of an hybrid articulated electric bus of the Hibriplus project - a Partnership of the Curitiba Transportation Agency, the Chassis Manufacturer Volvo and URBS (Urbanização de Curitiba S/A). Besides that, the project includes a number of studies and analysis of atmospheric emissions involving the urban transportation known as ParCur [19].

As a contribution, the update of the plan with focus on the total emissions taking into account the fuels production process until the consumer would be required, looking at the whole chain and not only at the urban vehicles emissions. Thinking that we have seasonal variations that might contribute to change the concentration of the main toxic pollutants, it would be worthy to apply a model verifying the climate conditions in the different seasons of the year. A deeper analysis of the quality of emissions of the urban vehicles fleet and the 
implementation of the vehicle inspection and maintenance are some of the details of the plan that have not been implemented yet. An extreme process of decarbonization is the replacement of the current diesel model in the bus fleet by biodiesel and electric buses.

\section{REFERENCES}

[1] Ministry of the Environment, Climate Changes and Environmental Quality Agency Climate Changes Department, Air Quality Management. First National Inventory of Atmospheric Emissions by Road Vehicles, IEMA - Institute of Energy and Environment: Brasilia, 2009.

[2] Sachs, J.D., The Age of Sustainable Development, Columbia University Press: New York, 2015.

[3] Vijayaraghavan, K., Lindhjem, C., Denbleyker, A., Nopmongcol, U., Grant, J., Tai, E. \& Yarwood, G., Effects of light duty gasoline vehicle emission standards in the United States on ozone and particulate matter. Atmospheric Environment 60 (2012) 109 e 120, Elsevier Ltd: Novato, CA, 2012.

[4] Houyoux, M.R., Vukovich, J.M., Coat, C.J. Jr. \& Wheeler, N.J.M., Emission inventory development and processing for the Seasonal Model for Regional Air Quality (SMRAQ) project. Durham, North Carolina. Journal of Geophysical Research, 105(d7), pp. 9079-9090, 2000. DOI: 10.1029/1999JD900975

[5] CE Delft, Fraunhofer IML, TRT, Ecorys \& Conlogic., Fact-Finding Study in Support of the Development of an EU Strategy for Freight Transport Logistics, European Commission DG for Mobility and Transport: CE Delft, 2014.

[6] Prevedouros, P.D. \& Mitropoulos, L.K., Life Cycle Emissions and Cost Study of Light Duty Vehicles, Transportation Research Procedia, Vol. 15, Elsevier Ltd: Honolulu, pp. 749-760, 2016

[7] EPA - Environmental Protection Agency (EPA) and the National Highway Traffic Safety Administration (NHTSA), available at https://www3.epa.gov/otaq/climate/ regs-light-duty.htm (accessed 20 September 2016).

[8] CONAMA - Conselho Nacional do Meio Ambiente - Resolução Conama 418, de 25 de novembro de 2009., available at http://www.mma.gov.br/port/conama/legiabre. cfm?codlegia8 (accessed 20 September 2016).

[9] Plano de Controle de Poluição Veicular - elaborado pela Secretária de Recursos Hídricos e Meio Ambiente do Estado do Paraná, available at http://www.iap.pr.gov. br/arquivos/File/Legislacao_ambiental/Legislacao_estadual/RESOLUCOES/PCPV_ Estado_do_Parana.pdf (accessed 22 September 2016).

[10] Instituto Brasileiro de Geografia e Estatística - IBGE, available at http://www.ibge.gov. br/apps/populacao/projecao/index.html (accessed 22 September 2016).

[11] Agência Nacional do Petróleo, Gás Natural e Biocombustíveis - ANP, available at http://www.anp.gov.br/ (accessed 5 October 2016).

[12] Departamento Nacional de Trânsito - DENATRAN, available at http://www.denatran. gov.br/ (accessed 20 September 2016).

[13] de Melo Álvares Alvares, O. Jr. \& Linke, R.R.A., Metodologia simplificada de cálculo das emissões de gases do efeito estufa de frotas de veículos no Brasil, Companhia de Tecnologia de Saneamento Ambiental do Estado de São Paulo - CETESB: São Paulo, 2000.

[14] GREET® Model, The Greenhouse Gases, Regulated Emissions, and Energy Use in Transportation Model and the Argonne National Laboratory's Systems Assessment Group, available at http://www.anl.gov/energy-systems (accessed 27 September 2016). 
[15] Minitab Statistical Software, available at http://www.minitab.com/pt-br/products/ minitab/ (accessed 5 August 2016).

[16] Neema, M.N., Jahan, J., An innovative approach to mitigate vehicular emission through roadside greeneries: A case study on Arterial Roads of Dhaka City. Journal of Data Analysis and Information Processing, 2014, 2, 32-39, SCIRP Dhaka: Bangladesh, 2014.

[17] Instituto Ambiental do Paraná-IAP., available at http://www.iap.pr.gov.br/pagina-1076. html (accessed 22 September 2016).

[18] Resolution SEMA No016 - Of April 15 2014., available at http://www.legislacao. pr.gov.br/legislacao/listarAtosAno.do?action=exibir\&codAto7128\&indice=1\&total RegistrosR\&anoSpan 15\&anoSelecionado 14\&mesSelecionado=0\&isPaginado=true (accessed 22 September 2016).

[19] NordicLight - A Joint Swedcham/NBCC Publication., May and June 2016, available at http://www.swedcham.com.br/publico/nordic-light/Nordic-Light-Apr2016-May2016. pdf (accessed 9 October 2016). 